Tropical Journal of Pharmaceutical Research November 2017; 16 (11): 2629-2635

ISSN: $1596-5996$ (print); 1596-9827 (electronic)

(c) Pharmacotherapy Group, Faculty of Pharmacy, University of Benin, Benin City, 300001 Nigeria.

All rights reserved.

Available online at http://www.tjpr.org

Original Research Article

http://dx.doi.org/10.4314/tjpr.v16i11.9

\title{
Effect of natural antioxidants on the aggregation and disaggregation of beta-amyloid
}

\author{
Jae-Eun Lee, Min-Suk Kim and So-Young Park* \\ Laboratory of Phramacognosy, College of Pharmacy, Dankook University, Cheonan 330-714, Korea
}

*For correspondence: Email: soypark23@dankook.ac.kr; Tel: +82 41550 1434; Fax: +82 5597899

Sent for review: 9 July 2017

Revised accepted: 16 October 2017

\begin{abstract}
Purpose: To examine the relationship between higher antioxidant activity and aggregation or disaggregation of beta-amyloid $(A \beta)$ for 21 plants.

Methods: Twenty-nine natural plant extracts and their antioxidant activities were analyzed using DPPH assay. The aggregation and disaggregation of $A \beta$ were analyzed using Thioflavin- $T$ assay.

Results: Eleven plant extracts exhibited high antioxidant activities with the half-maximal inhibitory concentration $\left(I C_{50}\right)$ values $<20.0 \mu \mathrm{g} / \mathrm{mL}$. Furthermore, the plant extracts efficiently inhibited $A \beta$ aggregation with a mean $I C_{50}$ value of $17.0 \mu \mathrm{g} / \mathrm{mL}$. However, four plant extracts exhibiting low antioxidant activities $\left(I C_{50}>80.0 \mu \mathrm{g} / \mathrm{mL}\right.$ ) inhibited $A \beta$ aggregation less efficiently with a mean $I C_{50}$ value of $75.7 \mu \mathrm{g} / \mathrm{mL}$. Furthermore, plant extracts with high antioxidant activities were not invariably efficient for disaggregating pre-formed $A \beta$ aggregates.

Conclusion: High antioxidant activities were positively correlated with the inhibition of A $\beta$ aggregation, although not with the disaggregation of pre-formed $A \beta$ aggregates. Nevertheless, potent antioxidants may be helpful in treating Alzheimer's disease.
\end{abstract}

Keywords: Alzheimer's disease, $\beta$-Amyloid, Aggregation, Disaggregation, Antioxidants

Tropical Journal of Pharmaceutical Research is indexed by Science Citation Index (SciSearch), Scopus, International Pharmaceutical Abstract, Chemical Abstracts, Embase, Index Copernicus, EBSCO, African Index Medicus, JournalSeek, Journal Citation Reports/Science Edition, Directory of Open Access Journals (DOAJ), African Journal Online, Bioline International, Open-J-Gate and Pharmacy Abstracts

\section{INTRODUCTION}

$\beta$-amyloid $(A \beta)$ is a polypeptide of $36-43$ amino acids, and is a major causative factor of Alzheimer's disease $(A D)$. $A \beta$ aggregation into senile plaques is a pathological characteristic detected in the brains of patients with $A D$. $A \beta$ is produced by the sequential cleavage of amyloid precursor proteins by $\beta$ - and $y$-secretases. $A \beta$ molecules undergo self-aggregation to form oligomers and fibrils, which cause neurotoxicity via oxidative stress, disturb calcium homeostasis, and induce mitochondrial dysfunction, and neuroinflammation. Thus, the discovery of compounds or extracts that inhibit $A \beta$ aggregation, and induce the disaggregation of $A \beta$ aggregates could be an effective approach to the therapy and prevention of $A D$.

Antioxidants are molecules that scavenge free radicals and reactive oxygen species (ROS), which can induce oxidative stress, and consequently, cellular damages. Antioxidant intake is helpful in preventing human diseases [1]. For example, antioxidants can reduce the risk of cardiovascular diseases by inhibiting vascular inflammation, lipid peroxidation, and platelet aggregation [2]. Additionally, antioxidants are known to have anti-cancer, anti-diabetic, and anti-aging effects [3-5]. Antioxidants are also considered helpful in treating AD, because the ROS generated in $A D$ pathology causes neuronal damage [6]. Furthermore, certain 
antioxidants such as polyphenols inhibit $A \beta$ aggregation, and destabilize preformed $A \beta$ aggregates $[7,8]$. However, the relationships between antioxidant activity and inhibition of $A \beta$ aggregation, and between antioxidant activity and disaggregation of preformed $A \beta$ aggregates are not analyzed. Therefore, in this study, 29 natural plant extracts with diverse antioxidant activity were analyzed for effects on the aggregation and disaggregation of $A \beta$, and the correlation between them was analyzed as well.

\section{EXPERIMENTAL}

\section{Materials and reagents}

Thioflavin T (ThT), DPPH, and dimethyl sulfoxide (DMSO) were purchased from Sigma-Aldrich (MO, USA). Ethanol and methanol were purchased from Samchun (Pyeong-Taek, Korea). $A \beta_{1-42}$ was purchased from GL Biochem (Shanghai, China).

\section{Plant materials}

Twenty-nine plant materials (Table 1) were purchased from a commercial market (Samhing medicinal herb market; Seoul, Korea) in 2014. One of the authors (S-Y Park) performed botanical identification and voucher specimens were deposited in Pharmacognosy laboratory of College of Pharmacy, Dankook University.

\section{Preparation of plant extracts}

Dried and pulverized plant materials were extracted 3 times with $90 \%$ methanol at room temperature. The $\mathrm{MeOH}$ filtrate was evaporated under vacuum to yield the $\mathrm{MeOH}$ extract. Each extract was dissolved in DMSO and stored at -20 ${ }^{\circ} \mathrm{C}$ until use for the assay.

\section{Antioxidant assay}

The antioxidant activities of the plant extracts were determined using a stable free radical, $\mathrm{DPPH}$. The ability of the plant extracts to scavenge DPPH, and convert it to 1,1-diphenyl2-picrylhydrazine was determined colorimetrically. In brief, the plant extracts at different concentrations of $(4,20$, and 100 $\mu \mathrm{g} / \mathrm{mL})$ were mixed with $190 \mu \mathrm{L}$ of DPPH $(0.316$ $\mathrm{mM}$ in ethanol) and the mixtures were incubated at $37^{\circ} \mathrm{C}$ for $30 \mathrm{~min}$. The optical density values of the mixtures were measured at $517 \mathrm{~nm}$ with a microplate reader (Molecular Devices, Sunnyvale, CA, USA). All measurements were conducted out at least thrice.

\section{ThT assay of inhibition of $A \beta$ aggregation}

To quantify $A \beta$ aggregates, the ThT assay was performed. $A \beta_{1-42}$ was dissolved in DMSO at 1 $\mathrm{mL}$, and stored at $-20{ }^{\circ} \mathrm{C}$ until use. To monitor their effects on $A \beta$ aggregation, the plant extracts $(4,20$, and $100 \mu \mathrm{g} / \mathrm{mL})$ were incubated with 20 $\mu \mathrm{M}$ of $\mathrm{A} \beta(49 \mu \mathrm{L})$ at $37^{\circ} \mathrm{C}$ for $24 \mathrm{~h}$. Then, $3 \mu \mathrm{M}$ of ThT $(50 \mu \mathrm{L})$ was added, and the fluorescence was measured after $30 \mathrm{~min}$ with an EMax precision microplate reader (Molecular Devices) with excitation at $442 \mathrm{~nm}$ and emission at 485 $\mathrm{nm}$. A $\beta$ treated with DMSO was used as the control, and each assay was performed in triplicate.

\section{ThT assay of disaggregation of preformed $A \beta$ aggregates}

To monitor the effects of the plant extracts on the disaggregation of the $A \beta$ aggregates, $20 \mu \mathrm{M}$ of $\mathrm{A} \beta(49 \mu \mathrm{L})$ was incubated at $37^{\circ} \mathrm{C}$. After $24 \mathrm{~h}$, the plant extracts $(4,20$, and $100 \mu \mathrm{g} / \mathrm{mL})$ were added, and incubated for an additional $24 \mathrm{~h}$. Subsequently, $3 \mu \mathrm{M}$ of ThT $(50 \mu \mathrm{L})$ was added, and the fluorescence was measured as described in the previous section.

\section{Statistical analysis}

Data were expressed as means \pm SD. Two or more group comparisons were performed by one-way analysis of variance (ANOVA), followed by Tukey's post-hoc test (SPSS version 17.0; IBM SPSS, Armonk, NY, USA). Differences were considered statistically significant at $P<0.05$.

\section{RESULTS}

\section{Antioxidant effects of the plant extracts}

The results of DPPH assay showed that Agrimonia pilosa, Cornus officinalis, Rubus coreanus, Sophora japonica, and Paeonia suffruticosa exhibited strong antioxidant effects with $I_{50}$ values below than $10 \mu \mathrm{g} / \mathrm{mL}$. Contrastingly, Houttuynia cordata, Torilis japonica, Rehmannia glutinosa, and Arisaema erubescens exhibited relatively poor antioxidant activities with $\mathrm{IC}_{50}$ values higher than $100 \mu \mathrm{g} / \mathrm{mL}$ (Table 1).

\section{Inhibition of $A \beta$ aggregation by the plant extracts}

The ThT assay demonstrated that Cornus officinalis exhibited the highest inhibitory effect on $A \beta$ aggregation with an $I_{50}$ value of 8.2 $\mu \mathrm{g} / \mathrm{mL}$ (Table 1). 
Table 1: List of some plant species, and their antioxidant, anti-amyloidogenic and $A \beta$ disaggregating activities

\begin{tabular}{|c|c|c|c|c|}
\hline Plant & Plant part used & $\begin{array}{l}\text { Antioxidant } \\
\text { effect } \\
\left(I_{50}, \mu g / m L\right)\end{array}$ & $\begin{array}{l}\text { Inhibition } \\
\text { of } A \beta \\
\text { aggregation } \\
\left(\mathrm{IC} \mathrm{C}_{50}\right. \\
\mu \mathrm{g} / \mathrm{mL})\end{array}$ & $\begin{array}{l}\text { Disaggregation } \\
\text { of } A \beta \\
\text { aggregates } \\
\left(E D_{50}, \mu \mathrm{g} / \mathrm{mL}\right)\end{array}$ \\
\hline $\begin{array}{l}\text { Agrimonia pilosa Ledebour } \\
\text { (Rosaceae) }\end{array}$ & Whole plant & 5.1 & 9.1 & 102.3 \\
\hline $\begin{array}{l}\text { Amomum villosum Loureiro } \\
\text { (Zingiberaceae) }\end{array}$ & Fruit/Seed & 17 & 13.8 & 39.9 \\
\hline $\begin{array}{l}\text { Arisaema erubescens Schott } \\
\text { (Araceae) }\end{array}$ & Root & 90.9 & 98.3 & 114.2 \\
\hline $\begin{array}{l}\text { Chelidonium majus Linn\&eacute; } \\
\text { var. asiaticum Ohwi (Papaveraceae) }\end{array}$ & Aerial parts & 78.2 & 72.4 & 104.2 \\
\hline $\begin{array}{l}\text { Chrysanthemum zawadskii Herbich } \\
\text { var. latilobum (Maxim.) Kitamura } \\
\text { (Compositae) }\end{array}$ & Whole plant & 27.8 & 46.4 & 179.7 \\
\hline $\begin{array}{l}\text { Cimicifuga heracleifolia Komarov } \\
\text { (Ranunculaceae) }\end{array}$ & Rhizome & 52.7 & 76.1 & 115.7 \\
\hline $\begin{array}{l}\text { Cornus officinalis Siebold et } \\
\text { Zuccarini (Cornaceae) }\end{array}$ & Fruit & 5.3 & 8.2 & 42.1 \\
\hline Cyperus rotundus L (Cyperaceae) & Rhizome & 26 & 15.2 & 42.9 \\
\hline $\begin{array}{l}\text { Drynaria fortunei J. Smith } \\
\text { (Polypodiaceae) }\end{array}$ & Rhizome & 19.7 & 16.1 & 134.9 \\
\hline $\begin{array}{l}\text { Epimedium koreanum Nakai } \\
\text { (Berberidaceae) }\end{array}$ & Aerial parts & 46.8 & 39.4 & 110.6 \\
\hline $\begin{array}{l}\text { Eucommia ulmoides Oliver } \\
\text { (Eucommiaceae) }\end{array}$ & Leaves & 72.5 & 56.1 & 234.1 \\
\hline $\begin{array}{l}\text { Houttuynia cordata Thunberg } \\
\text { (Saururaceae) }\end{array}$ & Aerial parts & 134.4 & 99.3 & 276.4 \\
\hline $\begin{array}{l}\text { Hovenia dulcis Thunb } \\
\text { (Rhamnaceae) }\end{array}$ & Fruit/Seed & 31.4 & 46.6 & 124.6 \\
\hline $\begin{array}{l}\text { Leonurus japonicus Houttuyn } \\
\text { (Labiatae) }\end{array}$ & Aerial parts & 64.1 & 47.9 & 25.7 \\
\hline $\begin{array}{l}\text { Magnolia obovata Thunberg } \\
\text { (Magnoliaceae) }\end{array}$ & Bark & 30 & 49.3 & 130.3 \\
\hline Morus alba Linne (Moraceae) & Leaves & 74.2 & 44.5 & 73.8 \\
\hline $\begin{array}{l}\text { Myristica fragrans Houttuyu } \\
\text { (Myristicaceae) }\end{array}$ & Seed & 59 & 51.3 & 88.4 \\
\hline $\begin{array}{l}\text { Paeonia lactiflora Pall } \\
\text { (Ranuculaceae) }\end{array}$ & Root & 10 & 24.4 & 48.2 \\
\hline $\begin{array}{l}\text { Paeonia suffruticosa Andrews } \\
\text { (Paeoniaceae) }\end{array}$ & Root bark & 7.8 & 20.8 & 92.9 \\
\hline plantago asiatica L (Plantaginacea) & Seed & 12.8 & 20.6 & 127.7 \\
\hline Prunella vulgaris L (Labiatae) & Stem & 14.6 & 24.8 & 45 \\
\hline $\begin{array}{l}\text { Rehmannia glutinosa Liboschitz ex } \\
\text { Steudel (Scrophulariaceae) }\end{array}$ & Root & 109.5 & 80.2 & 396.9 \\
\hline Rubus coreanus Miquel (Rosaceae) & Fruit & 6 & 12.8 & 146.1 \\
\hline $\begin{array}{l}\text { Schizonepeta tenuifolia Briquet } \\
\text { (Labiatae) }\end{array}$ & Flower & 29.8 & 32.1 & 57.7 \\
\hline $\begin{array}{l}\text { Scrophularia buergeriana Miquel } \\
\text { (Scrophulariaceae) }\end{array}$ & Root & 53.8 & 72.8 & 67.4 \\
\hline Sophora japonica L (Leguminosae) & Flower & 7.1 & 25.2 & 134.3 \\
\hline Thuja orientalis L (Curpressaceae) & Leaves & 16.7 & 10.8 & 14.7 \\
\hline $\begin{array}{l}\text { Torilis japonica Decandolle } \\
\text { (Umbelliferae) }\end{array}$ & Fruit & 100.9 & 87.5 & 377.6 \\
\hline $\begin{array}{l}\text { Zingiber officinale Roscoe } \\
\text { (Zingiberaceae) }\end{array}$ & Rhizome & 65.7 & 47.2 & 137.4 \\
\hline
\end{tabular}


$A \beta$ incubation with $100 \mu \mathrm{g} / \mathrm{mL} \quad$ C. officinalis reduced the extent of $A \beta$ aggregation to $23 \%$, compared with the DMSO-treated control groups (Figure 1A). Similarly, Thuja orientalis and Agrimonia pilosa had strong inhibitory effects on $A \beta$ aggregation with $\mathrm{IC}_{50}$ values of 9.1 and 10.8 $\mu \mathrm{g} / \mathrm{mL}$ (Table 1), respectively. T. orientalis and $A$. pilosa at $100 \mu \mathrm{g} / \mathrm{mL}$ reduced $A \beta$ aggregation to $16.5 \%$ and $26.2 \%$, respectively, compared with the DMSO-treated control groups (Figure 1A). However, Torilis japonica, Arisaema erubescens, and Houttuynia cordata were less efficient in inhibiting $A \beta$ aggregation, and their $\mathrm{IC}_{50}$ values were $87.5,98.3$ and 99.3, respectively (Table 1 ). Incubation with $100 \mu \mathrm{g} / \mathrm{mL} T$. japonica, $A$. erubescens, and $H$. cordata reduced $A \beta$ aggregation to $47.2 \%, 49.9 \%$, and $43.6 \%$, whereas these plant extracts at $4 \mu \mathrm{g} / \mathrm{mL}$ exhibited negligible inhibitory effects on $A \beta$ aggregation (Figure 1B).

\section{Effects of the plant extracts on disaggrega- tion of $A \beta$ aggregates}

The disaggregating effects of the 29 plant extracts on pre-aggregated $A \beta$ aggregates were determined by the ThT assay. Thuja orientalis exhibited the highest disaggregating activity among the 29 plant extracts with an $\mathrm{IC}_{50}$ value of $14.7 \mu \mathrm{g} / \mathrm{mL}$ (Table 1). Similarly, Leonurus japonicus efficiently induced the disaggregation of preformed $A \beta$ aggregates with an $I_{50}$ value of $25.7 \mu \mathrm{g} / \mathrm{mL}$. Contrarily, the effects of Torilis japonica and Rehmannia glutinosa on the disaggregation of preformed $A \beta$ aggregates were extremely minimal with $\mathrm{IC}_{50}$ values of 377.6 and $396.9 \mu \mathrm{g} / \mathrm{mL}$, respectively.

\section{Antioxidant activity and inhibition of $A \beta$ aggregation}

To determine the relationship between the inhibition of $A \beta$ aggregation and antioxidant activity, twenty-nine plants were divided into 4 groups based on the $\mathrm{IC}_{50}$ values for antioxidant activity (group 1, IC $\mathrm{C}_{50}$ value: $0-20$; group $2, \mathrm{IC}_{50}$

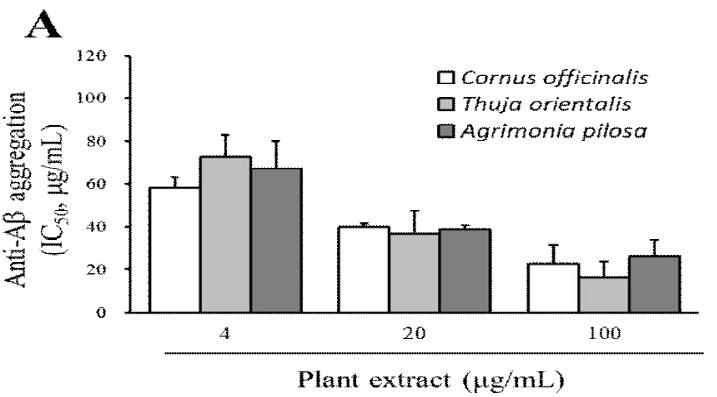

value: $21-50$; group $3, I_{50}$ value: $51-80$, and group $4, I C_{50}$ value over 81 ). The average $I C_{50}$ values for the antioxidant activities of the groups $1,2,3$, and 4 were $11.1,32.0,65.0$, and 86.1 $\mu \mathrm{g} / \mathrm{mL}$, respectively (Figure $2 A$ ), whereas the average $\mathrm{IC}_{50}$ values for anti- $\mathrm{A} \beta$ aggregation in the groups $1,2,3$, and 4 were 17.0, 38.2, 58.5 and $75.7 \mu \mathrm{g} / \mathrm{mL}$, respectively. The average $\mathrm{IC}_{50}$ value for anti- $A \beta$ aggregating activities of the plant extracts in group 1 was significantly lower than those of the groups 2, 3, and 4. These results indicated that the plant extracts with higher antioxidant activities exhibited higher anti$A \beta$ aggregating activities. Therefore, plants with higher antioxidant activities could be beneficial for patients with $A D$ because of their possibly higher anti-A $\beta$ aggregating activities.

\section{Antioxidant activity and disaggregation of $A \beta$ aggregates}

To determine the relationship between antioxidant activity and the disaggregation of $A \beta$ aggregates, the mean $\mathrm{IC}_{50}$ values of groups 1-4 for the disaggregation of $A \beta$ aggregates were compared (Figure $2 \mathrm{C}$ ). The average $\mathrm{IC}_{50}$ values of the groups $1,2,3$, and 4 for $A \beta$ disaggregation were 84.3, 107.6, 105.8, and $291.2 \mu \mathrm{g} / \mathrm{mL}$, respectively. Group 1 exhibited a relatively low $I_{50}$ value for $A \beta$ disaggregation; however, it was not significantly different from those of groups 2 and 3 . However, the disaggregating activities of groups 1,2 , and 3 were significantly different from that of group 4 .

\section{DISCUSSION}

Natural products containing polyphenolic compounds, such as berries, spices, and green tea, are known to have antioxidant and neuroprotective activities. Furthermore, the neuroprotective effects of natural polyphenolic compounds, such as myricetin and luteolin are exerted, at least partially, by attenuating $A \beta$ induced toxicity [9].

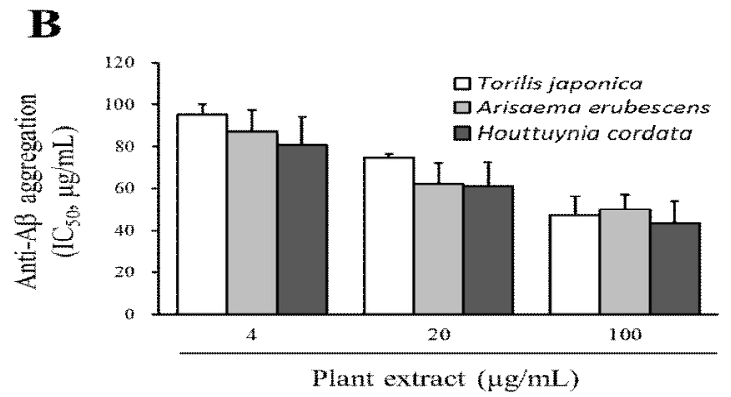

Figure 1: Anti-amyloidogenic effects of the plant extracts. (A) Anti- A $\beta$ aggregation effects of the plant extracts, such as Cornus officinalis, Thuja orientalis and Agrimonia pilosa, with high antioxidant activity $\left(\mathrm{IC}_{50}<16.7\right.$ $\mu \mathrm{g} / \mathrm{mL}$ ). (B) Anti-A $\beta$ aggregation effects of the plant extracts, such as Torilis japonica, Arisaema erubescens, and Houttuynia cordata, with low antioxidant activity $\left(\mathrm{IC}_{50}>90 \mu \mathrm{g} / \mathrm{mL}\right)$. 

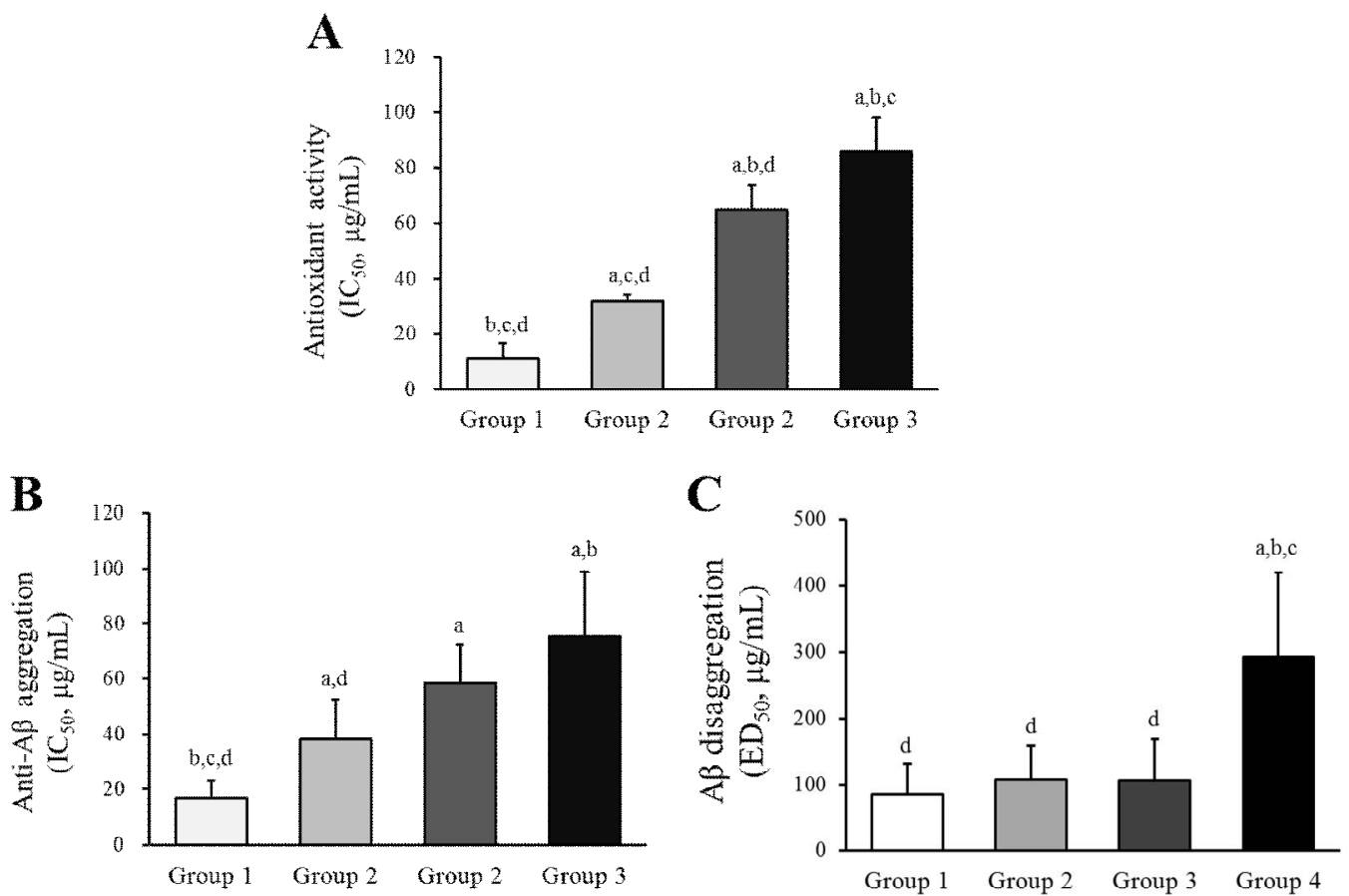

Figure 2: Mean values of the antioxidant, anti-A $\beta$ aggregating and $A \beta$-disaggregating activities of 29 plant extracts divided into 4 groups based on antioxidant activity. (A) Average values of antioxidant activities, (B) average values of anti- $A \beta$ aggregating activities and $(C)$ average values of $A \beta$-disaggregating activities. ${ }^{a} P<$ 0.05 , different from Group 1, ${ }^{b} P<0.05$, different from Group 2, ${ }^{c} P<0.05$, different from Group $3,{ }^{d} P<0.05$, different from Group 4

However, this does not indicate that potent antioxidants are efficient in the inhibition of $A \beta$ aggregation and disaggregation of $A \beta$ aggregates. Therefore, in this study, the relationships between antioxidant activity and inhibition of $A \beta$ aggregation, and between antioxidant activity and disaggregation of preformed $A \beta$ aggregates were examined.

The aggregation of $A \beta$ monomers to form oligomers and fibrils (aggregates) induces neurotoxicity. Oxidative stress, induced during $A \beta$ aggregation, disrupts synapses, and impairs the functions of synapses and membranes $[10,11]$. Thus, antioxidants could be helpful in treating $A D$ by reducing oxidative stress-related neuronal damage. Additionally, the use of compounds or extracts inhibiting $A \beta$ aggregation is considered a good approach to the therapy and prevention of $A D$. For example, flavonoids such as myricetin, quercetin, and kaempferol inhibited $A \beta$ aggregation (exhibited antiamyloidogenic activities) [12-14]. Additionally, rosmarinic acid and curcumin are other compounds that inhibit $A \beta$ aggregation efficiently $[15,16]$. Interestingly, these compounds are known to have high antioxidant activities. Consistent with previous reports, our results suggested that the plant extracts with relatively high antioxidant activity inhibited $A \beta$ aggregation efficiently. This could be because potent antioxidants, such as polyphenols, in the plant extracts interact with aromatic regions in $A \beta$, disrupt the self-assembly of $A \beta$ into $\beta$-sheet conformational stacking, and eventually, inhibit $A \beta$ aggregation [17].

Antioxidants are also considered efficient in disaggregating $A \beta$. Curcumin and $\beta$-carotene exhibited high $A \beta$-disaggregating activities owing to their symmetric rod-like structures and hydrophobic moieties that wedged into $A \beta$ cores, and disrupt the $\beta$-sheet structures $[18,19]$. However, the increases in hydrophilicity reduced $A \beta$-disaggregating activity [18]. Furthermore, morin is an efficient $A \beta$-disaggregating flavonoid. The aromatic moiety and hydrogen-bonding capacity of morin are suggested to cause the disaggregation of $A \beta$ aggregates [20]. These reports suggest that molecules with hydrophobicity, aromatic moiety, and hydrogen bonding-capacity might, at least, partially contribute to the disaggregation of $A \beta$ aggregates. Consistent with these results, our study similarly suggested that antioxidants are not invariably positively correlated with high $A \beta-$ disaggregating activity. Altogether, these results suggested that the plant extracts with high antioxidant activities are efficient in inhibiting $A \beta$ aggregation; however, they were not invariably efficient in disaggregating $A \beta$ aggregates. Nonetheless, antioxidants could be beneficial for patients with $A D$ owing to their possible anti-A $\beta$ aggregating and $A \beta$-disaggregating activities. 


\section{CONCLUSION}

Twenty-nine plant extracts have been analyzed for antioxidant, anti-amyloidogenic, and $A B$ disaggregating activities. The plant extracts with high antioxidant activity inhibit $A \beta$ aggregation more efficiently than those with low antioxidant activity; however, antioxidant activity correlates weakly with the disaggregation of pre-formed $A \beta$ aggregates. Nevertheless, good antioxidants may be helpful in treating $A D$.

\section{DECLARATIONS}

\section{Acknowledgement}

This work was supported by Research Fund of Dankook University in the form of a grant to one of the authors (SY Park) in 2015.

\section{Conflict of Interest}

No conflict of interest associated with this work.

\section{Contribution of Authors}

The authors declare that this work was done by the authors named in this article and all liabilities pertaining to claims relating to the content of this article will be borne by them.

\section{Open Access}

This is an Open Access article that uses a funding model which does not charge readers or their institutions for access and distributed under the terms of the Creative Commons Attribution License (http://creativecommons.org/licenses/by/ 4.0) and the Budapest Open Access Initiative (http://www.budapestopenaccessinitiative.org/rea d), which permit unrestricted use, distribution, and reproduction in any medium, provided the original work is properly credited.

\section{REFERENCES}

1. Wang J, Hu S, Nie S, Yu Q, Xie M. Reviews on Mechanisms of In Vitro Antioxidant Activity of Polysaccharides. Oxid Med Cell Longev 2016; 2016. 5692852

2. Adegbola $P$, Aderibigbe I, Hammed W, Omotayo $T$. Antioxidant and anti-inflammatory medicinal plants have potential role in the treatment of cardiovascular disease: a review. Am J Cardiovasc Dis 2017; 20177: 19-32

3. Wu X, Cheng J, Wang X. 2017. Dietary Antioxidants: Potential Anticancer Agents. Nutr Cancer 2017; 69: 521 533
4. Eid HM, Haddad PS. The Antidiabetic Potential of Quercetin: Underlying Mechanisms. Curr Med Chem 2017; 24: 355-364

5. Obrenovich ME, Nair NG, Beyaz A, Aliev G, Reddy VP. The role of polyphenolic antioxidants in health, disease, and aging. Rejuvenation Res 2010; 13: 631-643

6. Manoharan S, Guillemin GJ, Abiramasundari RS, Essa MM, Akbar M, Akbar MD. The Role of Reactive Oxygen Species in the Pathogenesis of Alzheimer's Disease, Parkinson's Disease, and Huntington's Disease: A Mini Review. Oxid Med Cell Longev 2016; 2016: 8590578

7. Xie H, Wang JR, Yau LF, Liu Y, Liu L, Han QB, Zhao Z, Jiang $Z H$. Catechins and procyanidins of Ginkgo biloba show potent activities towards the inhibition of betaamyloid peptide aggregation and destabilization of preformed fibrils. Molecules 2014; 19: 5119-5134

8. Pasinetti GM. Novel role of red wine-derived polyphenols in the prevention of Alzheimer's disease dementia and brain pathology: experimental approaches and clinical implications. Planta Med 2012; 78: 1614-1619

9. Ma H, DaSilva NA, Liu W, Nahar PP, Wei Z, Liu Y, Pham $P T$, Crews $R$, Vattem $D A$, Slitt $A L$, et al. Effects of a Standardized Phenolic-Enriched Maple Syrup Extract on beta-Amyloid Aggregation, Neuroinflammation in Microglial and Neuronal Cells, and beta-Amyloid Induced Neurotoxicity in Caenorhabditis elegans. Neurochem Res 2016; 41: 2836-2847

10. Mattson MP. Pathways towards and away from Alzheimer's disease. Nature 2004; 430:631-639

11. Butterfield DA, Drake J, Pocernich C, Castegna A. 2001. Evidence of oxidative damage in Alzheimer's disease brain: central role for amyloid beta-peptide. Trends $\mathrm{Mol}$ Med 2001; 7: 548-554

12. Hamaguchi $T$, Ono K, Murase A, Yamada M. Phenolic compounds prevent Alzheimer's pathology through different effects on the amyloid-beta aggregation pathway. Am J Pathol 2009; 175: 2557-2565

13. Jimenez-Aliaga K, Bermejo-Bescos P, Benedi J, MartinAragon S. Quercetin and rutin exhibit antiamyloidogenic and fibril-disaggregating effects in vitro and potent antioxidant activity in APPswe cells. Life Sci 2011; 89: 939-945

14. Sharoar MG, Thapa A, Shahnawaz M, Ramasamy VS, Woo ER, Shin SY, Park IS. Keampferol-3-O-rhamnoside abrogates amyloid beta toxicity by modulating monomers and remodeling oligomers and fibrils to nontoxic aggregates. J Biomed Sci 2012; 19: 104

15. Ono K, Hasegawa K, Naiki H, Yamada M. Curcumin has potent anti-amyloidogenic effects for Alzheimer's betaamyloid fibrils in vitro. J Neurosci Res 2004; 75: 742-750

16. Yamada M, Ono K, Hamaguchi T, Noguchi-Shinohara $M$. Natural Phenolic Compounds as Therapeutic and Preventive Agents for Cerebral Amyloidosis. Adv Exp Med Biol 2015; 863: 79-94

17. Ahmad E, Ahmad A, Singh S, Arshad M, Khan AH, Khan RH. A mechanistic approach for islet amyloid polypeptide aggregation to develop anti-amyloidogenic agents for type-2 diabetes. Biochimie 2011; 93: 793-805

Trop J Pharm Res, November 2017; 16(11): 2634 
18. Ono $K$, Yoshiike $Y$, Takashima A, Hasegawa $K$, Naiki $H$, Yamada M. Vitamin A exhibits potent antiamyloidogenic and fibril-destabilizing effects in vitro. Exp Neurol 2004; 189: 380-392

19. Das S, Stark L, Musgrave IF, Pukala T, Smid SD. Bioactive polyphenol interactions with beta amyloid: a comparison of binding modelling, effects on fibril and aggregate formation and neuroprotective capacity. Food Funct 2016; 7: 1138-1146

20. Lemkul JA, Bevan DR. Destabilizing Alzheimer's Abeta(42) protofibrils with morin: mechanistic insights from molecular dynamics simulations. Biochem 2010; 49: 3935-3946. 